\title{
The Paradox of Secrecy: Merchant Families, Family Firms, and the Porous Boundaries between Private and Public Business Life in Late Medieval and Early Modern Europe
}

\author{
Thomas Max Safley
}

Late medieval and early modern merchant-financiers expected their partners and employees to guard company secrets. In the case of one firm, Ambrosius und Hans die Gebrüder Höchstetter und Mitgesellschafter, their charter of 1515 required all signatories to preserve all business information from all outsiders: Every partner 'njemands weder fremden noch freunden gantz nicht weder wenig noch fill offenbaren sunder das suo gutter geheim pej im und untter uns behalten' (would reveal to no one, whether stranger or friend, anything great or small, but rather keep it secret to himself or among us). ${ }^{1}$ A decade later, the firm's 1524 charter extended the prohibition even to immediate family members, 'es seyen weyber, schwestern, prueder oder annder freunden nix ausgenommen' ('be it wives, sisters, brothers, or other relations without exception'). ${ }^{2}$ The Höchstetters clearly laid great emphasis upon the closed nature of their company.

The speculative character of business necessitated secrecy. Up-to-date information about warehouse contents, price movements, or business plans, whether circulated with intent or through carelessness, could damage the interests of a firm. Industrial espionage occurred frequently and had to be prevented. Jakob II ('the Rich') Fugger (1459-1525) and his successors regularly ordered their factors to gather information and render reports on the activities of competitors. ${ }^{3}$ Their competitors treated the Fuggers with equal regard. Their business accounts capture explicitly the importance of secrecy,

1 Stadtarchiv Augsburg, Höchstetter-Sammlung, Handelshaus, Nr. 1, Ambrosius und Hans Gebrueder die Hoechstetter und Gesellschaft. Gesellschaftsvertrag vom 19. Dez. 1515.

2 Stadtarchiv Augsburg, Reichsstadt Akten, Höchstetter-Selekt I, Höchstetter'scher Gesellschaftsbrief 1524. Also transcribed in Lutz E., Die rechtliche Struktur süddeutscher Handelsgesellschaften in der Zeit der Fugger, vol. 2 (Tübingen: 1976) 39-48.

3 Ortner R., Die Handlungsgehilfe, in besonderen der Faktor des süddeutschen Kaufmannes im 15. Und 16. Jahrhundert (Ph.D. dissertation, University of Munich: 1932) 68, footnote 2. See also

(C) THOMAS MAX SAFLEY, 2022 | DOI:10.1163/9789004153073_012

This is an open access chapter distributed under the terms of the CC BY-NC-ND 4o license. 
of guarding one's own secrets (and penetrating those of others). The principal account book in double-entry book-keeping, where not only final financial records but also business documents were kept, was referred to commonly as the 'Geheimbuch' ('secret book'). In his Handel Buch, one of the first German-language handbooks of business practices, published in 1558, Lorenz Meder quite deliberately exposed what merchants had long held secret. As his editor Hermann Kellenbenz points out: 'Er war der erste im deutschen Sprachgebiet, der auf die Geheimhaltung verzichtete, und es bedurfte noch verschiedener Generationen, bis dieses Tabu endgültig überwunden war' ('He was the first in the German-speaking world to renounce secrecy, and it would require a number of generations finally to overcome this taboo') ${ }^{4}$ Even Jacques Savary, author of Le parfait négociant (1675), arguably the most influential business handbook written before the nineteenth century, had to defend himself against the accusation of revealing secret knowledge. 5

Savary's prefatory remarks suggest the ambiguity and paradox of secrecy. They may be considered as much rhetorical and substantial, but the very fact that he felt called upon to make them suggests a certain unease with exposure of knowledge that was, if not strictly 'secret', then certainly arcane and sensitive. Any Geheimbuch might contain copies of documents that might be considered 'public' in the sense that contracts, etc. record transactions in a manner that explicitly fixes their contents to prevent opportunism and enforce observance, if necessary, through legal, public sanctions. Moreover, the corporate nature of premodern commercial life, captured in guild memberships and endogenous social interactions results in a certain ambiguity as to the actual secrecy of any business dealings. Yet, the oaths commonly required of business partners, to say nothing of the efforts by bankrupts to prevent 'secret books' from falling into the hands of the creditors, leaves little doubt about their intended secrecy.

Mohr C., Die Anfänge der modernen Warenspekulation im 15. Und 16. Jahrhundert (Ph.D. dissertation, University of Munich: 1927).

4 Meder Lorenz, Handel Buch. Darin angezeigt wird/welcher gestalt inn den fürnembsten Hendelstetten Europe/allerley Wahren anfencklich kaufft/diselbig wider mit nutz verkaufft/ Wie die Wechsel gemacht/Pfund/Ellen/unnd Müntz uberal verglichen/und zu welcher zeit die Merckten gewönlich gehalten werden. Sampt anderen mehr nutzungen darzu gehörig. Allen Hanthieren/und Jungen Kauffleuten/gantz nützlich und dienstlich (Nuremberg, Johann von Berg und Ulrich Newber: 1558). See Kellenbenz H., Handelsbräuche des 16. Jahrhunderts. Das Meder'sche Handelsbuch und die Welser'schen Nachträge (Wiesbaden: 1974) 72.

5 Savary Jacques, Le parfait négociant: ou instruction générale pour ce qui regarde le commerce des marchandises de France, \& des pays étrangers, ed. E. Richard (Geneva: 2011 [1675]). On the influence of this work, see Trivellato F., The Promise and Peril of Credit: What a Forgotten Legend about Jews and Finance Tells Us about the Making of European Commercial Society (Princeton, NJ: 2019). 
In practice, therefore, different kinds of knowledge required different levels of secrecy, which might encourage different levels of indiscretion.

The Höchstetters knew well the costs of exposing such things. Their violent dispute with a former bookkeeper and stakeholder, Bartholomäus III Rem (ca. 1481-1525), cost them a fortune in financial and social capital and led directly to their strict demand for secrecy. Yet, in 1528, faced with bankruptcy, Ambrosius I Höchstetter (1463-1534) confessed to Anton Fugger (1493-156o), heir and nephew of Jakob II and director (Regierer) of the largest and most powerful merchant-banking house in Augsburg, perhaps in all of Europe, that he could not master the tides that threatened to sweep him and his firm away. ${ }^{6} \mathrm{He}$ opened his firm's books to the scrutiny of an outsider and, in doing so, placed his fate and his firm in the hands of his most powerful competitor. Without consulting any member of his firm or his family, he violated the maxim of secrecy as generally practised by all early modern merchants and as specifically mandated by his family firm's charters of 1515 and 1524 .

Fugger did not hesitate. His reading of the accounts convinced him that Höchstetter could not be saved. ${ }^{7}$ Nor did he wish to save him. He shared the information with a number of his most powerful colleagues, including Hans II Paumgartner (1487-1549) and Bartholomäus v Welser (1484-1561). With their assistance, he agreed to pay many of Höchstetter's most important creditors, taking possession of Höchstetter's most valuable assets - mines, foundries, commodities, and loans - as assurance of repayment. Then, having plundered it, he allowed the Höchstetter firm to fail.

This essay takes up what I call 'the paradox of secrecy' within the business community and in early modern society. Using personal correspondence and legal documents, it explores the dynamic between a community of merchants that demanded secrecy, yet violated it opportunistically, and a society that viewed secrecy with the deepest misgivings, even sought to render it impossible. Secrecy meant different things to different people and could be used in different ways, depending on context and circumstance. Given the ambivalence of secrecy, given that supposedly closed structures and spaces remained

6 Fürstlich und Gräflich Fuggersches Familien- und Stiftungsarchiv Dillingen, Handel 2, 2, 1, Gemischte Korrespondenz der Administration der gemeinen Handels, 1527-1638; u.a. betr. Hoechstetter-Konkurs, 1527-1542, fol 1. Also quoted in full in Kern E., Studien zur Geschichte des Augsburger Kaufmannshauses der Höchstetter (Berlin: 1935) 35-37.

7 Fürstlich und Gräflich Fuggersches Familien- und Stiftungsarchiv Dillingen, Gemeiner Handel und Auslösung, 2.2.1 1/2, v-17. See also, Safley T.M., Family Firms and Merchant Capitalism in Early Modern Europe: The Business, Bankruptcy and Resilience of the Höchstetters of Augsburg (Abingdon: 2020). 
open to scrutiny and sanction, the secret and the overt were negotiated constantly at every threshold.

\section{$1 \quad$ Secrecy Considered}

By taking up 'secrecy', this essay examines a small, somewhat obscure aspect of 'privacy'. The Oxford English Dictionary defines the term predicatively as 'kept from public knowledge, or from the knowledge of persons specified; not allowed to be known, or only by selected persons', which usage appeared in English at the end of the fourteenth century. ${ }^{8}$ It might imply stealth or skulduggery: Something 'done or entered into with the intention of being concealed; clandestine'. And, with specific reference to business records from the mid-fifteenth century, it described 'some fact, affair, design, action, etc., the knowledge of which is kept to oneself or shared only with those whom it concerns or to whom it has been confided, something that cannot be divulged without violation of a command or breach of confidence'.

This is not pedantry: It relates to a less common interpretation of 'private' as something 'kept or removed from public view or knowledge,' ${ }^{9}$ and of privacy as 'the state or condition of being alone, undisturbed, or free from public attention, ${ }^{10}$ both of which derive from the classical Latin prìvatus, meaning 'restricted for the use of a particular person or persons, of or relating to a private person, not holding public office'. But, unlike private and privacy, which describe a generally, socially recognised and shared state or condition in contradistinction to that which is public, secrecy emphasises the agency of the individual, the particular, or idiosyncratic capacity of one person to conceal something from a wider world. It does not involve a social convention, pacé Georg Simmel and his followers, though it forms (and deforms) social relations. ${ }^{11}$ The agency involved in 'consciously desired concealment' -

8 'secret, adj. and n.', oED Online. March 2019. Oxford University Press. http://proxy.library .upenn.edu:2817/view/Entry/174537?rskey=wZgJjL\&result=1, accessed on 13 March 2019. 'private, adj.1, adv., and n., oED Online. March 2019. Oxford University Press. http:// proxy.library.upenn.edu:2817/view/Entry/1516o1?rskey=oUDsEg\&result=1, accessed on 13 March 2019.

10 'privacy, n., oEd Online. March 2019. Oxford University Press. http://proxy.library.upenn .edu:2817/view/Entry/151596?redirectedFrom=privacy, accessed on 20 March 2019.

11 Simmel defined all social relations in terms of varying degrees of 'reciprocal knowledge' between persons. Hence, secrecy, which he takes up explicitly and at length as 'deliberate concealment' of such knowledge, is at the centre of his sociology. See Simmel G., "The Secret and the Secret Society", in Simmel G., The Sociology of Georg Simmel, trans. K.H. Wolff (Glencoe, IL: 1950) 307-376. 
Simmel's term ${ }^{12}$ - moves to the heart of Julie Inness's observation about privacy - which, I believe, applies more aptly to secrecy - that it 'may work by separating a realm of the agent's life from the access of others, or it may work by providing the agent with control over a realm of her life', that is, that secrecy is a matter of limited access and of personal control. ${ }^{13}$

This conjures the distinction between the German terms geheim and privat. Commonly translated as 'secret', the former contrasts more typically with the notion of 'public' in early modern Germany. ${ }^{14}$ Thus, a degree of terminological slippage occurs. Geheim signals a formal, institutional distinction, whereas privat suggests a matter of informal, personal disposition. The documents produced in their thousands by the Höchstetter bankruptcy do not use the latter term. Grimm indicates that the term is a neologism of the sixteenth century, derived like the English equivalent from the Latin privatus and applied 'überhaupt dem amtlichen, öffentlichen, allgemeinen, gemeinsamen entgegengesetzt' ('above all in contradistinction to the official, public, general, [or] common'). ${ }^{15}$ Individual agency appears to be essential to the distinction in German, therefore. Interestingly, as will become apparent, when the Höchstetters take up the term geheim, they evoke the general principle to evade individual culpability.

A secret exists, therefore, when one interested party deliberately withholds information from another. ${ }^{16}$ Awareness of that withholding can likewise be withheld. ${ }^{17}$ Nor is that withholding ethically or socially negative in and of

\footnotetext{
12 Ibidem, 317.

13 Inness J.C., Privacy, Intimacy, and Isolation (New York: 1992) 23. See also Spacks P.M., Privacy: Concealing the Eighteenth-Century Self (Chicago: 2003) 1-26.

14 Von Moos P., 'Öffentlich' und 'privat' im Mittelalter. Zu einem Problem der historischen Begriffsbildung (Heidelberg: 2004) 45. See also Wunder's contribution to this volume.

15 Deutsches Wörterbuch von Jacob Grimm und Wilhelm Grimm. http://www.woerter buchnetz.de/DWB?bookref=13,2137,28. Referenced 10 June 2020. See also Hölscher L., "Öffentlichkeit", in Brunner, O. - Conze, W. - Koselleck, R. (eds.), Geschichtliche Grundbegriffe: Historisches Lexikon zur politisch-sozialen Sprache in Deutschland, vol. 4 (Stuttgart: 1978) 413-467.

16 Simmel's original point has been appropriated and expanded by others, notably Joachim Westerbarkey. See Westerbarkey J., Das Geheimnis. Zur funktionalen Ambivalenz von Kommunikationsstrukturen (Opladen:1991) 226. Given that every social exchange contains varying degrees of exposure and concealment (another of Simmel's observations), Niklas Luhmann argued that 'jede Vorsicht in Kommunikation bereits Geheimhaltung' ('every circumspection in communication contains secrecy'). See Luhmann N., "Geheimnis, Zeit und Ewigkeit", in Luhmann N. - Fuchs P. (eds.), Reden und Schweigen (Frankfurt a.M.: 1989) 101.

17 Burkhart Sievers made the distinction between 'simple' and 'reflexive' secrecy to emphasise the substantial difference between secrets that are acknowledged and those that are not. See Sievers B., Geheimnis und Geheimhaltung in sozialen Systemen (Opladen: 1974).
} 
itself, a fact that such value-free formulations as 'consciously desired concealment' or 'intentional concealment' attempt to bring forward. ${ }^{18}$ Hence, in the hands of social theorists, secrecy becomes not only the fact of concealment but the act of concealing, a mode of communication and a form of social interaction, but one abstracted from its social context and meaning. More recent historical studies tend to strip secrecy of abstraction, showing it to be, perhaps, not morally freighted in itself, but potentially disruptive, even dangerous, for individuals and communities. Secrecy, in the form of limited access or of personal control might offer advantages to the secret-holders, but for the societies of which they were part, secrecy might have a very significant 'functional meaning. 19

Herein lies the security of merchants, reflected in both the Höchstetters' chartered mandates and Meder's and Savary's published exposés: Undisclosed business information and practice increased competitive advantage in markets and marketplaces. And, herein lies the danger for society, recognised in some historical studies and implied in the theories of Michel Foucault and his followers: Secrecy allows an individual space both to review and to reject 'publicly' accepted standards of behaviour, those internalised social values that influence individual perceptions, away from strictures and sanctions of 'public' authorities. ${ }^{20}$

\section{Secrets Exposed}

Secrecy is precisely what creditors and authorities feared in late medieval and early modern business life. For them, it equalled subterfuge, concealed

18 Again, Simmel's classical treatment remains formative for the discussion of secrecy, a fact reflected in the many contemporary reformulations that do not substantially revise his initial observations. See, by way of example, Bok S., Secrets: On the Ethics of Concealment and Revelation (New York: 1989) 9.

19 This notion comes forward in studies of secret societies. See, for example, van Dülmen R., Geheimbund der Illuminaten. Darstellung, Analyse, Dokumentation (Stuttgart: 1975) 116. See also Koselleck R., Kritik und Krise. Eine Studie zur Pathogenese der bürgerlichen Welt (Frankfurt a.M.: 1973). Daniel Jütte seizes upon this notion as well in his study of Jewish intellectuals as purveyors of 'arcane' knowledge in early modern Europe. Like Simmel, who tended to elide the distinctions between the secret and the private, Jütte instrumentalises the more dramatic term to capture interest in something essentially different. His work has little to do with secrecy strictu sensu or with economy, see Jütte D., Das Zeitalter des Geheimnisses. Juden, Christen und die Ökonomie des Geheimen (1400-1800) (Göttingen: 2011).

20 Foucault M., "The Subject and Power", in Dreyfus H.L. - Rabinow P. (eds.), Michel Foucault: Beyond Structuralism and Hermeneutics (Chicago: 1983) 208-226. 
shenanigans. To prevent such behaviours, medieval officials insisted with astonishing unanimity that commercial transactions take place in public, in designated marketplaces, or at trade fairs, where transparency was the goal under the watchful eyes of the market police as well as consumers and colleagues in general. Goods were open to close inspection; prices were clearly indicated; negotiations could be easily overheard; violations were readily visible; reputations were immediately affected. Producers and merchants resisted such restrictions, not to cheat their customers, but to maximise their profits. Accordingly, they violated civic and regional market statutes and gradually moved their custom to shops and bourses, venues that permitted greater freedom of and discretion in retail and wholesale exchange, venues that enabled a degree more secrecy.

By the sixteenth century, Augsburg was one of the largest, free imperial cities in the Holy Roman Empire, titular seat of a prince-bishop, but a communal authority onto itself. It was a landlocked industrial centre, its fortunes guided by a native merchant community with stable colonies and factories in all the major and many minor economic centres of Europe. In the loggia at the foot of the city's watchtower, positioned next to the city hall, the great wholesale merchants set their changing tables and spread their commercial wares. Strung along the main thoroughfare, daily and weekly retail markets took place. Patrician palaces and mercantile comptoirs (trading houses) lined either side, among which could be seen the guildhalls of the city's powerful artisanal corporations. Down the side streets and alleys, barely visible behind these striking symbols of the city's political power, economic vitality, and social stratification, lay the industrial districts. Every type of craft and every degree of wealth could be found in every part of the city, but they were not equally distributed throughout it. ${ }^{21}$ Topography reflected society; both were hierarchical. Geographic distance from the centre signalled social distance from the top. In general, hierarchical societies resolve themselves into strata, defined by legal status, economic function, and political power. ${ }^{22}$ Birth right or privilege determined an individual's place in the hierarchy, a place that brought with it specific behavioural expectations and limitations. Such a structure might appear static, with each member assigned a given place and with little

21 The distribution of population according to wealth and occupation is based on an analysis of tax records from 1610. See Clasen C.-P., "Arm und Reich in Augsburg vor dem Dreißigjährigen Krieg”, in Gottlieb G. - Baer W. - Becker J. - Bellot J. - Filser K. - Fried P. Reinhard W. - Schimmelpfennig B. (eds.), Geschichte der Stadt Augsburg von der Römerzeit bis zur Gegenwart (Stuttgart: 1984) 312-336.

This definition is developed in greater detail in Schulze W., "Die ständische Gesellschaft des 16./17. Jahrhunderts als Problem von Statik und Dynamik", in Schulze W., (ed.), Ständische Gesellschaft und soziale Mobilität (Munich: 1988) 1-17. 
possibility of vertical mobility, but Augsburg was more dynamic than its topography suggests.

Beginning in the early-fifteenth century, the city entered a period of economic growth, based on the production of fustian, a cloth woven from linen and cotton. Manufacturing and commerce flourished and capital accumulated on the basis of international demand for this new drapery. ${ }^{23}$ Between 1396 and 1492, the estimated population rose from 12,00o to 19,000 as immigrants sought their fortunes in the shops and mills of Augsburg's burgeoning textile industry. ${ }^{24}$ New mercantile companies appeared, such as those of the Fugger, Höchstetter, Meuting, Rehlinger, and Welser families, some of whom would eventually join the ranks of the Augsburg patriciate. ${ }^{25}$ These parvenues traded in cloth and reinvested the profits in mining and banking. Growth accelerated in the sixteenth century, during which long-distance commerce and export-oriented industries, especially fustian production and metalworking, continued to set the pace of economic life. The city's estimated population doubled from 20,000 at the beginning of the sixteenth century to more than 40,0oo by the first decade of the seventeenth. ${ }^{26}$ Its taxable wealth tripled even more quickly, rising from between 2.58 and 5.16 million Gulden in 1498 to between 8.46 and 16.92 million in $15544^{27}$ Concentration and inequality increased; distance expanded apace. The middling strata of Augsburg, those who rendered less than ten Gulden in taxes, grew 17.3 percent, compared to

23 Jahn J., "Die Augsburger Sozialstruktur im 15. Jahrhundert", in Gottlieb G. - Baer W. Becker J. - Bellot J. - Filser K. - Fried P. - Reinhard W. - Schimmelpfennig B. (eds.), Geschichte der Stadt Augsburg von der Römerzeit bis zur Gegenwart (Stuttgart: 1984) 1887-1893. See also Dirlmeier U., Untersuchungen zu Einkommensverhältnisse und Lebenshaltungskosten in oberdeutschen Städten des Spätmittelalters (Heidelberg: 1978); Geffcken P., Soziale Schichtung in Augsburg, 1396 bis 1512. Beitrag zu einer Strukturanalyze Augsburgs im Spätmittelalter (Munich: 1987).

24 Jahn, "Die Augsburger Sozialstruktur im 15. Jahrhundert" 188.

25 The struggle for upward mobility is captured in the journals kept by Burckhard Zink and Lucas Rem, see Greiff B., "Tagebuch des Lucas Rem aus den Jahren, 1494-1541. Ein Beitrag zur Handelsgeschichte der Stadt Augsburg", Jahresbericht des historischen Vereins für Schwaben und Neuburg 27 (1861) 1-110; Zink B., Bourkard Zink et sa chronique d'augsbourg (Geneva: 1868). For Zink, see also Wunder's contribution to this volume.

26 Rajkay B., "Die Bevölkerungsentwicklung von 1500 bis 1648", in Gottlieb G. - Baer W. Becker J. - Bellot J. - Filser K. - Fried P. - Reinhard W. - Schimmelpfennig B. (eds.), Geschichte der Stadt Augsburg von der Römerzeit bis zur Gegenwart (Stuttgart: 1984) 252-258.

27 Kellenbenz H., "Wirtschaftsleben der Blütezeit”, in Gottlieb G. - Baer W. - Becker J. Bellot J. - Filser K. - Fried P. - Reinhard W. - Schimmelpfennig B. (eds.), Geschichte der Stadt Augsburg von der Römerzeit bis zur Gegenwart (Stuttgart: 1984) 258-301, here 290. The differing assessment rates for moveable and real property necessitates the use of ranges rather than specific valuations. 
the have-nothings, who increased by 88 percent, and to the rich, those who rendered more than 100 Gulden in taxes, who increased by 94 percent. ${ }^{28}$ Of the city's tax-paying population, 7.5 percent of the city's population controlled 86 percent of its taxable wealth; 75 percent made do with 7.5 percent. ${ }^{29}$ The mercantile elite built urban palaces along the city's main thoroughfare, while the labouring poor crowded into the suburbs. It might be argued that spatial distance promoted the keeping of secrets even as social tension increased opposition to them.

As the 1529 bankruptcy of Ambrosius und Hans die Gebrüder Höchstetter und Mitgesellschafter and a host of other bankruptcies make clear, however, secrecy clauses and private venues were seldom entirely effective. Bankruptcy compelled exposure, strove for transparency. The earliest codification of local law, the Augsburger Stadtbuch of 1276 prescribed measures and sanctions for non-payment of debt and provided the point of departure for a centuries-long evolution of official procedures in cases of default. ${ }^{30}$ Initially, it offered creditors only 'Anspruch auf Gewett und Pfand' ('a claim to pledge and surety'), from which to satisfy their demands. ${ }^{31}$ The defaulting debtor had to appear before the magistrate, pledge payment and offer adequate surety to meet the obligation within a specified period of time. ${ }^{32}$ Should the debtor refuse to appear, fail to pay, or flee the city, the magistrate could order seizure of the debtor's property in place of payment. ${ }^{33}$ The principle of 'first come, first served' seems to have determined the priority of payment, though no edict officially mandated this practice. ${ }^{34}$ Over time and of necessity, the Augsburg magistracy established a single, public Gewett (pledge) in the presence of the Stadtvogt (city

28 Ibidem, 295-297.

29 Ibidem, 270. See also Clasen C.-P., Die Augsburger Steuerbücher um 1600 (Augsburg: 1976) $15^{-16 .}$

30 Bayrisches Hauptstaatsarchiv München, Reichsstadt Augsburg Literalien, Lit. 32. See also Meyer C. (ed.), Das Stadtbuch von Augsburg, insbesondere das Stadtrecht vom Jahre 1276, nach der Originalhandschrift zum ersten Male herausgegeben und erläutert (Augsburg: 1872); Schmidt R., "Zum Augsburger Stadtbuch von 1276", Zeitschrift des historischen Vereins für Schwaben 70 (1976) 80-179. On bankruptcy procedures, see Birnbaum S., Konkursrecht der frühen Augsburger Neuzeit mit seinen gemeinrechtlichen Einflüssen (Münster: 2014) 6 .

31 Birnbaum, Konkursrecht der frühen Augsburger Neuzeit 17.

32 See Liedl E., Gerichtsverfassung und Zivilprozeß der freien Reichsstadt Augsburg (Augsburg: 1958); Kießling R., Bürgerliche Gesellschaft und Kirche in Augsburg im Spätmittelalter (Augsburg: 1971) 54-57, here 67-68.

33 Hellmann F., Das Konkursrecht der Reichsstadt Augsburg (Breslau: 1905) 20.

34 Birnbaum notes what Hellmann observed nearly a century earlier that no official ordinances mark the early development of insolvency and bankruptcy regulation in Augsburg. Rather, the historian must rely on 'Randvermerke und Nachträge'. Birnbaum, Konkursrecht der frühen Augsburger Neuzeit 5, 22. 
bailiff) at which point all creditors were required to submit their just claims in person and to receive a pledge of payment from the debtor. ${ }^{35}$ That pledge included the classic cessio bonorum, a public oath to cease all business, open all accounts and cede all property to the creditors. Between 1564 and 159o, the Augsburg City Council passed a series of ordinances that finally enshrined into law the cumulative, common practice in cases of bankruptcy. ${ }^{36}$ That law prescribed an orderly, efficient settlement of bankruptcy through the official announcement of court hearings, the creation of a creditors' committee, the equal treatment of all creditors, the examination of bankrupts' account books, and the collective management of the bankrupt's capital. The bankrupts had to surrender their business records, including their 'secret book' to the authorities and creditors, opening to public scrutiny their secret business activities. In the case of the Höchstetters, those records proved that the bankrupts had violated their public oath to cease all business and cede all property. The exposure of their secret dealings contributed to the lasting ruin of their reputation, rendering them the most notorious monopoly capitalists of the age in the eyes of contemporaries and historians alike.

Witness testimony confirmed the written record with an intimacy of detail that reveals the irony of secrecy in a society that would have none of it. Officials and creditors examined and cross-examined a wide range of persons. These examinations followed a precise, formal ritual. Plaintiffs submitted a list of question for approval by the authorities. The authorities, usually a committee of three or four members of the City Court, put the questions to the accused, who swore an oath to answer truthfully. The questioning occurred in prison, in full view of the instruments of torture, a grim reminder, were any needed, that perjury could have immediate, painful consequences. Questions did not deviate from the approved lists, and answers were recorded in the third person by a city secretary. In brief, the formalities influenced the testimony: Questions led the witnesses to specific answers; answers served the instrumental purposes of the witnesses. The results should not be read transparently.

In the Höchstetter bankruptcy, questioning began with the factors and employees of the firm, especially a core group of nine, referred to as Geheimdiener (confidential employees), nearly all of whom had worked in responsible positions for the Höchstetters for more than a decade. Though individually responsible for the conduct of all business at important locations, the factors

35 Hellmann, Das Konkursrecht der Reichsstadt Augsburg 66.

36 Stadtarchiv Augsburg. Ordnungen und Statuten. Fallitenordnung, 1564, 1574, 1580. Cf. Häberlein M., Brüder, Freunde und Betrüger. Soziale Beziehungen, Normen und Konflikte in der Augsburger Kaufmannschaft um die Mitte des 16.Jahrhunderts (Berlin: 1998) 323-337. 
denied any knowledge of the removal or sale of property or goods, whether commercial wares and financial notes, in their individual factories and warehouses. Nor did they know to whom these assets might have been sold, mortgaged, or promised. They did not know about specific ventures; they did not know about specific transactions; they did not know about any business conducted after the bankruptcy declaration and the cessio bonorum.

For these 'confidential employees', all merchant-financiers in their own right, 'secrecy' served not merely as a chartered mandate to govern the behaviours of the firm's partners, but as a norm of the commercial community to be preserved at all costs. It also provided them a degree of ethical latitude, a degree of 'irresponsibility': The secrets they did not know, they could not divulge. ${ }^{37}$ The specificity of the questions they refused to answer suggests, however, that plausible deniability would not serve; the firm's secrets had already been exposed. It forced them to consider what further details to reveal. Asked about a suspicious transfer of assets in Tyrol, for example, they broke ranks. One factor said his transactions were a matter of record. Another admitted participating in the transfer but denied knowledge of it purpose. Yet another, the firm's bookkeeper, went so far as to say 'des mer er sye nit schuldig anzuzaigen' ('what was more, he was not liable to reveal') the interests or transactions of anyone else. ${ }^{38}$ In essence, their silence spoke more loudly than their words.

The creditors' attention shifted to persons - male and female, artisanal and mercantile, rich and poor, official and semi-official - who transferred, sold, and extended capital as a trade or profession. The Höchstetters made full use of them, and their creditors knew precisely where to find them.

Leonhard Pfister, the Unterkäufel of Augsburg testified that he had undertaken several transactions involving the Höchstetters, securing loans for them by using a variety of commercial and domestic goods as collateral. ${ }^{39}$ Unterkäufler were intermediaries (Makler) who brought together foreign and

37 The term is Simmel's. He recognised, as have other scholars after him, the fact that secrecy isolates and de-personalises the individual. Where members of a group - be it a secret society or a commercial company - are sworn to secrecy, they are not only bound by oath to conceal that which is deliberately held secret but also granted by oath ignorance of it. As he put it, '[...] the individual, as a person, disappears as the quasi-nameless group member, and with his disappearance as a person disappears the responsibility that cannot be imagined to inhere in a being whose concrete activities are intangible'. Simmel, The Sociology of Georg Simmel 375 .

38 Stadtarchiv Augsburg, Literaliensammlung, Höchstetter-Selekt I, Dok. 15, Urgichten 1531/32, 24 October 1531.

Ibidem, 27 October 1531 . 
local merchants for the purposes of financial or commercial transactions. ${ }^{40} \mathrm{In}$ this respect, they assumed some of the functions of a bourse, as other scholars have noted, before one existed as a physical locus of economic life and information in Augsburg. ${ }^{41}$ The arcade that stood at the foot of the city's bell tower was too public a venue for sensitive conversation and negotiation, however. When the Kaufleutestubengesellschaft (merchant association) acquired its Kaufleutestube, first in rented rooms near the city's wine market around 1480, then in a dedicated house in 1548, that place assumed many of the functions of a bourse, among other things providing a somewhat more discrete setting for private conversations and secret deals. Until that time, however, the Unterkäufler provided such mediation. They also served a fiscal function as officials, appointed by the city council to oversee all wholesale and financial transactions, to arrange a fair price and to assure the quality of the goods traded for the principal purpose of guaranteeing the city its tax (Ungeld) revenue. ${ }^{42}$ Pfister's testimony added specific detail to creditor accusations that the Höchstetters had for their own purposes liquidated fixed and moveable properties that should rightfully have been used to meet creditor demands.

Another figure who engaged in the buying and selling of various new and used goods was the Kramerzunftknecht (servant of the Shopkeepers' Guild). Like the Unterkäufler, he collected a civic tax, in this case on all retail sales that involved members of the Shopkeepers' Guild. ${ }^{43}$ Accordingly, a wide variety of goods passed through his hands, making him an ideal intermediary for the liquidation of moveable capital. Like Pfister, when questioned by the authorities, Otmar Fugger provided a lengthy inventory of wares - spices and textiles for the most part - that he had received and sold on behalf of the wives of the Höchstetter partners. ${ }^{4}$

40 For further discussion of the Unterkäufel and their role in financial markets, see Blendinger F., Zwei Augsburger Unterkaufbücher aus den Jahren 1551 bis 1558. Älteste Aufzeichnungen zur Vor- und Frühgeschichte der Augsburger Börse (Stuttgart: 1994); Fuhrmann B., Mit barer Münze. Handel im Mittelalter (Darmstadt: 2010); Geffken P., "Kaufleutestube", in Augsburger Stadtlexikon Online (Augsburg: 2010).https://www.wiss ner.com/stadtlexikon-augsburg/artikel/stadtlexikon/kaufleutestube/4359; Hetzer G. Zorn W., "Augsburger Börse", in Augsburger Stadtlexikon Online (Augsburg: 2010) https:// www.wissner.com/stadtlexikon-augsburg/artikel/stadtlexikon/boerse/3374. See Dirr P., "Kaufleutezunft und Kaufleutestube in Augsburg zur Zeit des Zunftregiments", Zeitschrift des Historischen Vereins für Schwaben 35 (1909) 132-151.

42 Blendinger, Zwei Augsburger Unterkaufbücher aus den Jahren 1551 bis $155^{8} 14$.

43 Ibidem, 15 .

44 Stadtarchiv Augsburg, Literaliensammlung, Höchstetter-Selekt I, Dok. 15, Urgichten 1531/32, 27 October 1531. 'Zettel. Zu merckhen was jch Othmair Fugger verkauft hab von 
In Augsburg, gold- and silversmiths also fulfilled intermediary roles, especially in the buying and selling of precious metals. ${ }^{45}$ Their traffic in gold and silver, their knowledge of current prices and their accumulated capital made them valuable figures in the financial market, sources of ready cash and credit, ersatz pawnbrokers and bankers. ${ }^{46}$ Joachim Nitzel admitted purchasing various silver pieces - jewelry and tableware - from the Höchstetters. ${ }^{47}$ The creditors wanted to question all 'gemain Verkaufferin wolcher Namen den Stattknecht wol bewisst' (common, female peddlers, whose names are very familiar to the police). ${ }^{48}$ They, too, functioned as intermediaries on the basis of their knowledge of the market in first- and second-hand wares of various sorts, which made them useful for liquidating personal items and housewares in order to raise quick cash. They worked with the bankrupts and their wives to sell everything from clothing and jewelry to silver plates and luxury textiles as well as modest, quotidien items, such as dishtowels, blankets, and underwear.

These intermediaries all dealt directly with the Höchstetters and their wives. They came into the family's houses, where they received the goods to be sold and, after the sale, paid the proceeds to the former owners in face-toface transactions. The bankrupts considered these dealings to be a thing apart: Personal property could be used to meet private needs and expenses without violating the terms of the interests of their creditors. Whatever their roles, such intermediaries give evidence of the manifold ways private and public were 'confounded' in early modern society. ${ }^{49}$ Not only were many acts of daily life

den Guter, die ich von Philip Gasner seligen empfangen hab, nemlich wie hernach stet 153028 Mai'.

45 See Rathke-Köhl S., Geschichte des Augsburger Goldschmiedegewerbes vom Ende des 17. bis zum Ende des 18. Jahrhunderts (Augsburg: 1964); Seling H., Die Kunst der Augsburger Goldschmiede 1529-1868 (Munich: 1980); idem, "Silberhandel und Goldschmiedekunst in Augsburg im 16. Jahrhundert", Welt im Umbruch, vol. 3 (Augsburg: 1981) 162-170; Werner A., Augsburger Goldschmiede: Verzeichnis der Augsburger Goldschmiede, Silberarbeiter, Juweliere und Steinschneider von 1346-1803 (Augsburg: 1913).

46 See de Roover R., The Rise and Fall of the Medici Bank, 1397-1494 (New York: 1966); Ehrenberg R., Capital and Finance in the Age of the Renaissance: A Study of the Fugger (New York: 1928); Kindelberger C.P., A Financial History of Western Europe, 2nd ed. (Oxford: 1993); Tawney R.H., "Introduction", in Wilson T., A Discourse on Usury, ed. R.H. Tawney (London: 1925 [1572]); van Dillen D.J., History of the Principal Public Banks (The Hague: 1934).

47 Stadtarchiv Augsburg, Literaliensammlung, Höchstetter-Selekt I, Dok. 15, Urgichten 1531/32, 29 Oktober 1531.

48 Ibidem, Dok. 11, Verhoersprotokolle, 1531/32.

49 The term is taken up by Philippe Ariès in his introduction to volume 3 of $A$ History of Private Life, but Norbert Elias originally observed that members of traditional societies publicly perform many private acts of daily life. See: Ariès P. - Duby G. (eds.), A History of 
performed in the open, but the community defined the boundaries. Attempts to preserve secrecy achieved thus a more subtle purpose: Some people, like the confidential employees, felt themselves 'not obliged to speak about what they did not see. ${ }^{50}$ Others, like the semi-public intermediaries reported only what was deliberately divulged and made manifest. Different groups in different circumstances understood - and instrumentalised - secrecy and transparency differently.

The creditors saw things otherwise: Secret dealings were intended to defraud them. From their perspective, these mediated transactions were of a piece with the nocturnal movements of servants and employees in and out of the various Höchstetter dwellings. Early modern cities did not lack for witnesses, however. Several testified to this highly suspicious activity:

[...] es seye etliche vier der funff Mal by nechtlicher weis zu seiner Gelegenhait, ye zu zehen, ye zu aylff, ye zu zwolff Urn fur des alten Ambrosy Hochstetters Haus anhaym gangen und gesehen zum Thor, darauff der Schreibstub stet, ain Zeichkarlin hinus furn, was als darob gewesen, wiss er nit, wer es aber herauss zogen oder wo dz hinkommen, trage er auch kain Wissen, dann er sich des nicht geachtet. ${ }^{51}$

It happened four or five times, at night between 10:00 PM and midnight as he went home: He would go past the house of Ambrosius I Höchstetter and see a handcart come out of the doorway that led to the chancery; he could not tell what was in the cart or who was pushing it, because it was night.

On the strength of this evidence, the creditors formulated a set of questions for 20 current and former servants of the Höchstetters and their partners. ${ }^{52}$ In late medieval and early modern society, servants might enjoy the status of famuli, that is, quasi-members of the household who enjoyed positions

Private Life, vol. 3, (Cambridge, MA: 1987/9o) 1-10, here 1; Elias N., The Civilizing Process: The History of Manners, trans. E. Jephcott (New York: 1982).

50 See Yves Castan's discussion in his "Politics and Private Life", in Ariès - Duby (eds.), A History of Private Life vol. 4 (Cambridge, MA: 1987/9o) 21-68, here 45.

51 Stadtarchiv Augsburg, Literaliensammlung, Höchstetter-Selekt I, Dok. 15, Urgichten 1531/32, 29 October 1531.

52 Stadtarchiv Augsburg, Literaliensammlung, Höchstetter-Selekt I, Dok. 11, Verhoersprotokolle, $1531 / 32$. 
of privilege and trust and who might be expected to demonstrate loyalty. 53 Whether out of loyalty or ignorance, nearly all of them denied any knowledge of goods removed from the houses of their masters.

Yet, a few offered revealing testimony. One woman, formerly in service to Hans I Höchstetter (1471-1427), admitted that she had carried bales of goods two or three times to the house of Lucas II Rem (1481-1541), a noteworthy merchant as well as former factor and partner of the Höchstetters. ${ }^{54}$ When questioned, Rem denied any involvement, but confirmed the suspicion. He was in Salzburg when his wife agreed to a request by Höchstetter's widow to keep several things of his in her house ('jne etlich Beraitschaft zu behalten'). ${ }^{55}$ When he returned home and learned of the situation, 'jme auch vast laid und wider gewesen' ('he was sorry and opposed to it'). He ordered his servants to return all of the transferred items and asked the widow to confirm receipt of them, all of which was done before a notary and witnesses.

Another, formerly a servant in Ambrosius I Höchstetter's household, revealed how her master's son and partner, Joachim I (1505-1535), managed to avoid the fate of his father by fleeing the city and taking 30,000 Gulden with him. ${ }^{56} \mathrm{He}$ made his way to Antwerp in the diplomatic retinue of Johan, Archbishop of Lund, the representative of King Christian II of Denmark to the Imperial Diet (Reichstag), then convened in Augsburg, but not before he

hab sein und jr Silbergeshir erschmelten und hinweg gefurt [...] dann er ein Schmelzoffen jm Hauss gehapt [...] ain Man zu Aratzried, als Joachim hinweg gezogen, hab er sein Wames voller Gulden eingenaeht ${ }^{57}$

had melted down and taken away [...] his and her silverware, as he had a melting oven in his household and a man in Adelsried [...] sewed the legs of Joachim's trousers full of Gulden

The inquiry goes on at great length, extending to members of the Merchant Corporation (Kaufleuteschaft) and the Höchstetter family. In every back alley,

53 See Maza S., Servants and Masters in Eighteenth-Century France: The Uses of Loyalty (Princeton, NJ: 1983). Of families, Castan writes: 'It was essential to be tight-lipped with outsiders concerning family matters: money and property, ambition, marriage and work were none of their business', Castan, "Politics and Private Life" 21-68, here 59.

Stadtarchiv Augsburg, Literaliensammlung, Höchstetter-Selekt I, Dok. 11, Verhoersprotokolle, $1531 / 3^{2}$.

55 Ibidem, Dok. 15, Urgichten 1531/32, 31 October 1531.

56 Ibidem.

57 Ibidem. 
doorway, and marketplace of Augsburg, people moved, goods changed hands, and information was shared. Even the supposedly intimate spaces and secrets of the household, from the comptoir to the boudoir, were not impervious to the self-interest of partners, the professional oversight of intermediaries, the prying eyes of neighbours, or the tattling tongues of servants. Merchants enjoined a secrecy that they did not keep, could not enforce, and their community would not respect. They might attempt to conceal, but they could not control.

\section{Conclusion}

At one point in the bankruptcy, the creditors directly questioned the imprisoned partners about the matter of secrecy. ${ }^{58}$ They wanted to know,

Dieweil jnn der letzten Gesellshaft Verschreibung unnder anndern Articuln ausstruckhenlich bedingt wurdt, das die Gesellschaffter unnd Diener etlich Hanndlungen und Anshleg bei guten Trewen jnn gehaim zuhallten, was dieselben Anshleg oder Hanndlungen gewesen, darumb er sy des Gehaims halben so hoch gegen jme verstrickht? ${ }^{59}$

as the most recent company charter expressly required among other things that the partners and employees keep secret in good faith various transactions and accounts, which were the ones that became so twisted for the sake of keeping them secret?

Ambrosius II (1501-1550) and Joseph (1502-1575) Höchstetter replied in chorus that they 'wiss nit anders dan gehaim zu halten jnn Handlungen' ('knew nothing other than to keep secrecy in business dealings'). ${ }^{60}$ This, of course, they did not do: Confronted with prison and dishonour they divulged all and blamed the senior partner, Ambrosius I, their father and uncle. He returned the favour, explaining phlegmatically that 'seie bei allenn Gesellschaften der Brauch jm Handlung verschwigen zu haltenn damit sie jnn Kaufen und Verkauffen nit gehindert werden, wiss sonst von keinem sondern Geheim' ('it was the common practice of all companies to keep their trade secrets, so that they were

58 Ibidem, Dok. 17, "Uff welhe Posten die Hochstetter mit Ernst anzusprechen sein".

59 Ibidem.

6o Stadtarchiv Augsburg Literaliensammlung, Höchstetter-Selekt I, Dok. 18, Actum 13. Aprilis Anno 32, jn praesentibus Herrn Wilhalm Rechlinger, Miller, Paler, Ambrosi der junger Hochsteter sagt an guetlicher Frag an. 
not hindered in buying and selling'). ${ }^{61}$ The partners in late medieval and early modern family firms enjoyed explicit freedom to conduct whatever business they saw fit, provided it profited the firm, and were under no obligation to divulge those transactions to other partners. ${ }^{62}$ Clearly, secrecy applied not only between insiders and outsiders, but also among the partners themselves. No less clearly, it applied selectively, even arbitrarily.

Ambrosius I Höchstetter was speaking of comparative, competitive advantage, something all merchants understood and sought, something they came to understand in terms of secrecy. Though not entirely unknown, explicit mandates to Geheimhaltung (secrecy) appear seldom in the charters of late medieval and early modern firms. ${ }^{63}$ Charters of the Fugger company specify as early as 1512 that all business matters 'should be kept quiet and revealed to no one', but they are an exception. ${ }^{64}$ The 1515 charter of Ambrosius und Hans die Gebrüder Höchstetter und Mitgesellschafter is thus not the first to include secrecy clauses, but it is certainly one of the earliest and most extreme instances. The requirement of discretion (Verschwiegenheit) appears with increasing frequency over the ensuing century until, by its close, it had emerged as a standard feature of business charters across the Empire as well as in the Low Countries and Italy. 65

The bankruptcies of the sixteenth century, of which the Höchstetters' has served here as a case in point, suggest the irony of secrecy. It seems to exist in a three-fold paradox: First, secrecy was a sworn oath that applied selectively; second, secrecy was a universal commitment but one that applied under specific circumstances; third, secrecy could be applied flexibly, almost instrumentally. The bankruptcy proceedings suggest that the paradox may be more apparent than real. The historical discussion of secrecy too often elides it with other

61 Ibidem, Dok. 20, Actum auf 13. Tag Aprilis Anno 32, jn praesentibus Herrn Wilhalm Rechlinger, Miller, Paler, alt Ambrosi Hochstetter zaigt an guetlicher Frag an.

62 There were exceptions, especially those firms that specified a single director (Regierer), such as the Fugger firm, who exercised sole and ultimate authority in all business matters. Fürstlich und Gräflich Fuggersches Familien- und Stiftungsarchiv Dillingen, 31.7, Gesellschaftsvertrag 1532 September 14. See also Lutz, Die rechtliche Struktur süddeutscher Handelsgesellschaften, vol. 1, 247-248, 267-272, and 282; vol. 2, 91-92; Strieder, J., Jacob Fugger the Rich, Merchant and Banker of Augsburg, 1459-1525 (New York: 1931) 69-70.

63 Lutz, Die rechtliche Struktur süddeutscher Handelsgesellschaften, vol. 1, 342-347.

64 From the charter of Jakob Fugger, signed on 30 December 1512, extending his company for six years. Cited by Jansen, M., Jacob Fugger der Reiche. Studien und Quellen, vol. 1 (Leipzig: 1910) 289-295, esp. 291.

65 The 1573 legal reforms of Frankfurt am Main, which came to serve as a standard guide for early modern business organisation, stated explicitly in $\S 1$ that secrecy was a contractual obligation of all signatories. Stadtarchiv Frankfurt am Main. Von 1578: Von Contracten, Der XXIII Titul. Von Gesellschafften (De societate). 
conditions, such as dishonesty (lying) and privacy. ${ }^{66}$ It has likewise become conflated in teleologies of modernity. ${ }^{67}$ Unlike privacy, secrecy conforms not to social convention that changes over time but to personal perspectives and individual agency. It was understood and utilised by different groups for different ends: For teachers like Meder and Savary, secret meant arcane, matters known only to the few cognoscenti; for practitioners like the Höchstetters and Fuggers, secret meant strategic, matters that provided advantage for those in the know; for their employees and neighbours, secret meant concealed but not sealed, matters to be exposed as circumstances dictated; for creditors and authorities, secret meant suspect, matters that caused disorder and loss. Economic behaviours remind us of the self-interested quality of secrecy: Its fungibility as a means to profit; its lability when circumstances change; its flexibility according to need. As we consider secrecy - and privacy - we should remain conscious that they are not essential concepts, but rather historically constructed means to historically contingent ends.

\section{Bibliography}

Ariès P. - Duby G. (eds.), A History of Private Life, 5 vols. (Cambridge, MA: 1987/9o).

Birnbaum S., Konkursrecht der frühen Augsburger Neuzeit mit seinem gemeinrechtlichen Einflüssen (Münster: 2014).

Blendinger F., Zwei Augsburger Unterkaufbücher aus den Jahren 1551 bis 1558. Älteste Aufzeichnungen zur Vor- und Frühgeschichte der Augsburger Börse (Stuttgart: 1994).

Bok S., Secrets: On the Ethics of Concealment and Revelation (New York: 1989).

Castan Y., "Politics and Private Life", in Ariès P. - Duby G. (eds.), A History of Private Life vol. 4, 21-68.

Clasen C.-P., Die Augsburger Steuerbücher um 1600 (Augsburg: 1976).

Clasen C.-P., "Arm und Reich in Augsburg vor dem Dreißigjährigen Krieg", in Gottlieb G. - Baer W. - Becker J. - Bellot J. - Filser K. - Fried P. - Reinhard W. Schimmelpfennig B. (eds.), Geschichte der Stadt Augsburg von der Römerzeit bis zur Gegenwart (Stuttgart: 1984) 312-336.

De Roover R., The Rise and Fall of the Medici Bank, 1397-1494 (New York: 1966).

66 Scholars commonly and justly attribute the mistake to Simmel, but it is no less true of more recent studies. See Jütte, Das Zeitalter des Geheimnisses, passim.

67 Ariès asserts that ' $[. .$.$] the entire history of privacy comes down to a change in the forms$ of sociability, from the anonymous social life of street, castle court, square, or village to a more restricted sociability centered on the family or even the individual'. The treatment of secrecy as a mode of communication limits it similarly. Ariès P., "Introduction", in Ariès - Duby (eds.), A History of Private Life, vol. 3, 1-10, here 9. 
Dirlmeier U., Untersuchungen zu Einkommensverhältnisse und Lebenshaltungskosten in oberdeutschen Städten des Spätmittelalters (Heidelberg: 1978).

Dirr P., "Kaufleutezunft und Kaufleutestube in Augsburg zur Zeit des Zunftregiments", Zeitschrift des Historischen Vereins für Schwaben 35 (1909) 132-151.

Ehrenberg R., Capital and Finance in the Age of the Renaissance: A Study of the Fugger (New York: 1928).

Elias N., The Civilizing Process: The History of Manners, trans. by E. Jephcott (New York: 1982).

Foucault M., "The Subject and Power", in Dreyfus H.L. - Rabinow P. (eds.), Michel Foucault: Beyond Structuralism and Hermeneutics (Chicago: 1983) 208-226.

Geffcken P., Soziale Schichtung in Augsburg, 1396 bis 1512. Beitrag zu einer Strukturanalyze Augsburgs im Spätmittelalter (Munich: 1987).

Greiff B., "Tagebuch des Lucas Rem aus den Jahren, 1494-1541. Ein Beitrag zur Handelsgeschichte der Stadt Augsburg", Jahresbericht des historischen Vereins für Schwaben und Neuburg 27 (1861) 1-110.

Häberlein M., Brüder, Freunde und Betrüger. Soziale Beziehungen, Normen und Konflikte in der Augsburger Kaufmannschaft um die Mitte des 16. Jahrhunderts (Berlin: 1998).

Hellmann F., Das Konkursrecht der Reichsstadt Augsburg (Breslau: 1905).

Hölscher L., "Öffentlichkeit”, in Brunner O. - Conze W. - Koselleck R. (eds.), Geschichtliche Grundbegriffe: Historisches Lexikon zur politisch-sozialen Sprache in Deutschland, vol. 4 (Stuttgart: 1978) 413-467.

Inness J.C., Privacy, Intimacy, and Isolation (New York: 1992).

Jahn J., "Die Augsburger Sozialstruktur im 15. Jahrhundert”, in Gottlieb G. - Baer W. Becker J. - Bellot J. - Filser K. - Fried P. - Reinhard W. - Schimmelpfennig B. (eds.), Geschichte der Stadt Augsburg von der Römerzeit bis zur Gegenwart (Stuttgart: 1984) 1887-1893.

Jansen M., Jacob Fugger der Reiche. Studien und Quellen, 2 vols. (Leipzig: 1910).

Jütte D., Das Zeitalter des Geheimnisses. Juden, Christen und die Ökonomie des Geheimen (1400-1800) (Göttingen: 2011).

Kellenbenz H., Handelsbräuche des 16. Jahrhunderts. Das Meder'sche Handelsbuch und die Welser'schen Nachträge (Wiesbaden: 1974).

Kellenbenz H., "Wirtschaftsleben der Blütezeit", in Gottlieb G. - Baer W. - Becker J. Bellot J. - Filser K. - Fried P. - Reinhard W. - Schimmelpfennig B. (eds.), Geschichte der Stadt Augsburg von der Römerzeit bis zur Gegenwart (Stuttgart: 1984) 258-301.

Kern E., Studien zur Geschichte des Augsburger Kaufmannshauses der Höchstetter (Berlin: 1935).

Kießling R., Bürgerliche Gesellschaft und Kirche in Augsburg im Spätmittelalter (Augsburg: 1971).

Kindelberger C.P., A Financial History of Western Europe, 2nd ed. (Oxford: 1993). 
Koselleck R., Kritik und Krise. Eine Studie zur Pathogenese der bürgerlichen Welt (Frankfurt a.M.: 1973).

Liedl E., Gerichtsverfassung und Zivilprozeß der freien Reichsstadt Augsburg (Augsburg: 1958).

Luhmann N., "Geheimnis, Zeit und Ewigkeit", in Luhmann N. - Fuchs P. (eds.), Reden und Schweigen (Frankfurt a.M.: 1989).

Maza S., Servants and Masters in Eighteenth-Century France: The Uses of Loyalty (Princeton, NJ: 1983).

Lutz E., Die rechtliche Struktur süddeutscher Handelsgesellschaften in der Zeit der Fugger, 2 vols. (Tubingen: 1976).

Meder Lorenz, Handel Buch. Darin angezeigt wird/welcher gestalt inn den fürnembsten Hendelstetten Europe/allerley Wahren anfencklich kaufft/diselbig wider mit nutz verkaufft/Wie die Wechsel gemacht/Pfund/Ellen/unnd Müntz uberal verglichen/und zu welcher zeit die Merckten gewönlich gehalten werden. Sampt anderen mehr nutzungen darzu gehörig. Allen Hanthieren/und Jungen Kauffleuten/gantz nützlich und dienstlich (Nuremberg, Johann von Berg und Ulrich Newber: 1558).

Meyer C. (ed.), Das Stadtbuch von Augsburg, insbesondere das Stadtrecht vom Jahre 1276, nach der Originalhandschrift zum ersten Male herausgegeben und erläutert (Augsburg: 1872).

Mohr C., Die Anfänge der modernen Warenspekulation im 15. Und 16. Jahrhundert (Ph.D. dissertation, University of Munich: 1927).

Ortner R., Die Handlungsgehilfe, in besonderen der Faktor des süddeutschen Kaufmannes im 15. Und 16. Jahrhundert (Ph.D. dissertation, University of Munich: 1932).

Rajkay B., "Die Bevölkerungsentwicklung von 1500 bis 1648”, in Gottlieb G. - Baer W. Becker J. - Bellot J. - Filser K. - Fried P. - Reinhard W. - Schimmelpfennig B. (eds.), Geschichte der Stadt Augsburg von der Römerzeit bis zur Gegenwart (Stuttgart: 1984) $25^{2-258 .}$

Rathke-Köhl S., Geschichte des Augsburger Goldschmiedegewerbes vom Ende des 17. bis zum Ende des 18. Jahrhunderts (Augsburg: 1964).

Safley T.M., Family Firms and Merchant Capitalism in Early Modern Europe: The Business, Bankruptcy and Resilience of the Höchstetters of Augsburg (Abingdon: 2020).

Savary Jacques, Le parfait négociant: ou instruction générale pour ce qui regarde le commerce des marchandises de France, \& des pays étrangers, ed. E. Richard (Geneva: $2011[1675])$.

Schmidt R., "Zum Augsburger Stadtbuch von 1276", Zeitschrift des historischen Vereins für Schwaben 70 (1976) 80-179.

Schulze W., "Die ständische Gesellschaft des 16./17. Jahrhunderts als Problem von Statik und Dynamik", in Schulze W. (ed.), Ständische Gesellschaft und soziale Mobilität (Munich: 1988) 1-17.

Seling H., Die Kunst der Augsburger Goldschmiede 1529-1868 (Munich: 1980). 
Seling H., "Silberhandel und Goldschmiedekunst in Augsburg im 16. Jahrhundert", Welt im Umbruch, vol. 3 (Augsburg: 1981) 162-170.

Sievers B., Geheimnis und Geheimhaltung in sozialen Systemen (Opladen: 1974).

Simmel G., "The Secret and the Secret Society", in Simmel G., The Sociology of Georg Simmel, trans. by K.H. Wolff (Glencoe, IL: 1950) 307-376.

Spacks P.M., Privacy: Concealing the Eighteenth-Century Self (Chicago: 2003).

Strieder, J., Jacob Fugger the Rich, Merchant and Banker of Augsburg, 1459-1525 (New York: 1931).

Tawney R.H., "Introduction", in Wilson T., A Discourse on Usury, ed. R.H. Tawney (London: 1925 [1572]).

Trivellato F., The Promise and Peril of Credit: What a Forgotten Legend about Jews and Finance Tells Us about the Making of European Commercial Society (Princeton, NJ: 2019).

Van Dillen D.J., History of the Principal Public Banks (The Hague: 1934).

Van Dülmen R., Geheimbund der Illuminaten. Darstellung, Analyse, Dokumentation (Stuttgart: 1975).

Von Moos P., 'Öffentlich' und 'privat' im Mittelalter. Zu einem Problem der historischen Begriffsbildung (Heidelberg: 2004).

Werner A., Augsburger Goldschmiede: Verzeichnis der Augsburger Goldschmiede, Silberarbeiter, Juweliere und Steinschneider von 1346-1803 (Augsburg: 1913).

Westerbarkey J., Das Geheimnis. Zur funktionalen Ambivalenz von Kommunikationsstrukturen (Opladen: 1991).

Zink B., Bourkard Zink et sa chronique d'augsbourg (Geneva: 1868). 